\title{
Micropropagation of Pinus peuce
}

\author{
D. STOJIČIĆ ${ }^{1}$, D. JANOŠEVIĆ ${ }^{2}$, B. UZELAC ${ }^{3 *}$, V. ČOKEŠA ${ }^{4}$ and S. BUDIMIR ${ }^{3}$
}

Faculty of Science and Mathematics, University of Niš, Višegradska 33, 18000 Niš, Serbia ${ }^{1}$ Institute of Botany and Botanical Garden, "Jevremovac" Faculty of Biology, University of Belgrade, Takovska 43, 11000 Belgrade, Serbia ${ }^{2}$ Institute for Biological Research "Siniša Stankovič", University of Belgrade, Bulevar despota Stefana 142, 11060 Belgrade, Serbia ${ }^{3}$ Institute of Forestry, Kneza Višeslava 3, 11000 Belgrade, Serbia ${ }^{4}$

\begin{abstract}
In Pinus peuce zygotic embryo culture grown on Gresshoff and Doy (1972; GD) basal medium, $2.22 \mu \mathrm{M}$ benzyladenine (BA) was superior in promoting adventitious bud induction during 4 weeks comparing to kinetin or BA + kinetin. Shoot elongation was achieved on half-strength GD medium devoid of plant growth regulators and containing activated charcoal. Pulse treatment with $1 \mathrm{mM}$ indole-3-butyric acid (IBA) for $2 \mathrm{~h}$, followed by transfer to half-strength GD medium, produced the most efficient rooting. Rooted shoots were transplanted to the greenhouse and plantlets continued to grow and developed into phenotypically normal plants. Up to 10 plants per explant can be obtained within 36 weeks from culture initiation.
\end{abstract}

Additional key words: adventitious buds, benzyladenine, conifers, Macedonian pine, micropropagation

Macedonian pine, Pinus peuce, is a tertiary relict species endemic to the Balkan Peninsula. This pine usually grows on high mountains, at altitudes between 800 and $2300 \mathrm{~m}$, on slopes on siliceous soils and rarely on carbonate soils (Vidaković 1982). The tree is ornamental, 35 - $40 \mathrm{~m}$ tall. Macedonian pine is tolerant to winter cold and wind exposure and is recommended as a tree suitable for planting on degraded and devastated soils. Because of the limited area of its natural distribution, this species requires special attention and implementation of measures for its conservation (Janković 1991).

Plant regeneration systems developed for conifer species typically employ embryonic tissues as starting material (Stange et al. 1999, Zhang et al. 2006, Vooková et al. 2010). Optimization of factors influencing each step of the micropropagation procedure is necessary for successful regeneration through adventitious bud induction (Kaul 1990). This study was conducted with the aim to manage plant regeneration of Pinus peuce via adventitious buds. To our knowledge this is the first report of plant regeneration in vitro of this valuable conifer tree.

Cones of Pinus peuce Gris. were collected from open pollinated trees in a seed orchard located on Mučanj mountain (Serbia). Prior to the experiments, seeds were removed from cones, washed under running tap water for $24 \mathrm{~h}$, surface disinfected in $25 \%$ sodium hypochlorite for $25 \mathrm{~min}$, and rinsed three times with sterile distilled water. Mature embryos were then excised from surrounding gametophytic tissue and grown on basal Gresshoff and Doy (1972; GD) culture medium as modified by Sommer et al. (1975). Ten embryos were placed horizontally in each $90 \mathrm{~mm}$ plastic Petri dish filled with $25 \mathrm{~cm}^{3}$ of the medium. Experiments were repeated twice to give

Received 21 July 2010, accepted 26 October 2010.

Abbreviations: AC - activated charcoal; BA - benzyladenine; GD - Gresshoff and Doy medium; IBA - indole-3-butyric acid; NAA - $\alpha$-naphtaleneacetic acid.

Acknowledgements: The Ministry of Education and Science of Serbia Grant $N^{\circ} 173015$, supported this research.

* Corresponding author: fax: (+381) 112761 433, e-mail: branka@ibiss.bg.ac.rs 
a total of 60 explants for each treatment. Unless stated otherwise, the medium was supplemented with $3 \%$ sucrose and solidified with $0.7 \%$ agar (Torlak, Belgrade, Serbia). The $\mathrm{pH}$ of the media was adjusted to 5.7 prior to autoclaving for $25 \mathrm{~min}$ at $115{ }^{\circ} \mathrm{C}$, and cultures were maintained at $25 \pm 2{ }^{\circ} \mathrm{C}$ under 16 -h photoperiod with irradiance of $47 \mu \mathrm{mol} \mathrm{m} \mathrm{m}^{-2} \mathrm{~s}^{-1}$. Auxin pulse-treated shoot cultures were maintained under the same conditions.

For adventitious bud induction the effect of BA (2.22, $4.40,11.10$ or $22.20 \mu \mathrm{M})$ or kinetin $(2.32$, or $4.60 \mu \mathrm{M})$ was tested. Apart from these, the combinations of $1.11 \mu \mathrm{M} \mathrm{BA}+1.16 \mu \mathrm{M}$ kinetin or $2.22 \mu \mathrm{M} \mathrm{BA}+2.32 \mu \mathrm{M}$ kinetin were also examined.

After bud induction, the explants were transferred to half-strength GD medium without growth regulators and supplemented with $2 \%$ sucrose and $0.5 \%$ activated charcoal (AC) to promote bud elongation. For root induction, elongated shoots were isolated, pulse-treated with $1 \mathrm{mM}$ solution of $\alpha$-naphtaleneacetic acid (NAA) or indole-3-butyric acid (IBA) for 2 or $5 \mathrm{~h}$, and then transferred to 0.5 GD supplemented with $2 \%$ sucrose. For each treatment 20 shoots were used, and experiments were repeated twice.

A large number of adventitious buds mostly formed on the swollen region between cotyledons and hypocotyl during fourth week of culturing on cytokinin treated embryos. When explants were transferred onto medium lacking plant growth regulators and containing activated charcoal, adventitious bud elongation was stimulated. Under these conditions buds also emerged along the cotyledons. The optimal concentration of BA for bud induction was $2.22 \mu \mathrm{M}$ when the treatment lasted 4 weeks (Table 1). Higher BA concentrations (11.10 and $22.20 \mu \mathrm{M})$ in the medium after 4-week treatment led to development of stunted and clustered buds. On the other hand average shoot length increased when shorter induction time, 1 - 3 weeks, was applied (Table 1). Explants cultured on kinetin and BA medium as well as explants cultured in the presence of kinetin alone developed fewer buds than those cultured over the same time period on media with BA (Table 1).

A greater number of elongated shoots were obtained when explants, with each successive transfer to the fresh medium containing $\mathrm{AC}(0.5 \%)$, were divided into smaller pieces.

After 16 weeks isolated shoots treated with $1 \mathrm{mM}$ NAA or IBA pulse for 2 or $5 \mathrm{~h}$ and then transferred to 0.5 GD produced roots. Pulse treatment with IBA was preferable alternative over NAA both in terms of shoot survival and root induction. Up to $33.33 \%$ of rhizogenesis was achieved in $67.5 \%$ of survived 2-h pulse IBA-treated shoots. Rooted plantlets with few needles and well developed roots were transferred to pots, and continued to grow as phenotypicaly normal plants (Fig. 1).

In Pinus peuce embryo culture, BA was superior in promoting adventitious bud induction comparing to
Table 1. Effect of cytokinin treatment on adventitious bud induction in $P$. peuce zygotic embryo culture. Explants were grown on GD induction medium and then transferred to the bud elongation medium for 4 weeks. Shoot length was measured 16 weeks after culture establishment. Means \pm SE, $n=60$. Means in the column followed by different letters are different according to Duncan multiple range test $(P \leq 0.05)$.

\begin{tabular}{|c|c|c|c|c|}
\hline $\begin{array}{l}\text { Time } \\
\text { [weeks] }\end{array}$ & Cytokinin & {$[\mu \mathrm{M}]$} & $\begin{array}{l}\text { Number of buds } \\
\left.\text { [explant }^{-1}\right]\end{array}$ & $\begin{array}{l}\text { Shoot length } \\
{[\mathrm{mm}]}\end{array}$ \\
\hline \multirow[t]{4}{*}{1} & \multirow[t]{16}{*}{ BA } & 2.22 & $2.12 \pm 0.76^{\mathrm{a}}$ & $5.21 \pm 0.76^{\mathrm{bc}}$ \\
\hline & & 4.40 & $2.85 \pm 0.72^{\mathrm{a}}$ & $5.04 \pm 0.70^{\mathrm{bc}}$ \\
\hline & & 11.10 & $2.88 \pm 0.95^{\mathrm{a}}$ & $5.75 \pm 0.94^{\mathrm{c}}$ \\
\hline & & 22.20 & $3.73 \pm 0.91^{\mathrm{a}}$ & $5.23 \pm 0.91^{\mathrm{bc}}$ \\
\hline \multirow[t]{4}{*}{2} & & 2.22 & $4.32 \pm 0.99^{b}$ & $5.66 \pm 0.69^{\mathrm{c}}$ \\
\hline & & 4.40 & $4.87 \pm 1.03^{b}$ & $5.13 \pm 0.89^{\mathrm{bc}}$ \\
\hline & & 11.10 & $4.40 \pm 0.95^{\mathrm{b}}$ & $4.77 \pm 0.91^{\mathrm{b}}$ \\
\hline & & 22.20 & $4.64 \pm 0.91^{\mathrm{b}}$ & $4.78 \pm 0.91^{\mathrm{b}}$ \\
\hline \multirow[t]{4}{*}{3} & & 2.22 & $9.03 \pm 0.95^{\mathrm{d}}$ & $4.67 \pm 0.74^{\mathrm{b}}$ \\
\hline & & 4.40 & $10.10 \pm 1.11^{\mathrm{d}}$ & $4.13 \pm 0.86^{\mathrm{b}}$ \\
\hline & & 11.10 & $6.17 \pm 0.74^{\mathrm{c}}$ & $3.76 \pm 0.85^{\mathrm{ab}}$ \\
\hline & & 22.20 & $7.11 \pm 0.86^{\mathrm{c}}$ & $3.80 \pm 0.91^{\mathrm{ab}}$ \\
\hline \multirow[t]{4}{*}{4} & & 2.22 & $15.12 \pm 0.99^{\mathrm{f}}$ & $3.77 \pm 0.69^{\mathrm{ab}}$ \\
\hline & & 4.40 & $12.95 \pm 1.03^{\mathrm{e}}$ & $3.03 \pm 0.78^{\mathrm{a}}$ \\
\hline & & 11.10 & $10.40 \pm 0.95^{\mathrm{d}}$ & $2.75 \pm 0.80^{\mathrm{a}}$ \\
\hline & & 22.20 & $10.10 \pm 0.91^{\mathrm{d}}$ & $2.32 \pm 0.80^{\mathrm{a}}$ \\
\hline \multirow[t]{2}{*}{4} & \multirow[t]{2}{*}{ KIN } & 2.32 & $5.32 \pm 0.65^{\mathrm{c}}$ & - \\
\hline & & 4.60 & $5.46 \pm 0.86^{\mathrm{c}}$ & - \\
\hline \multirow[t]{2}{*}{4} & \multirow[t]{2}{*}{$\mathrm{BA}+\mathrm{KIN}$} & $1.11+1.16$ & $5.12 \pm 0.85^{\mathrm{c}}$ & - \\
\hline & & $2.22+2.32$ & $5.33 \pm 0.83^{\mathrm{c}}$ & - \\
\hline
\end{tabular}

kinetin or combination of $\mathrm{BA}$ and kinetin. In $P$. massoniana embryo culture and in $P$. pinea cotyledon culture, BA also exerted stronger bud-inducing effect than any other cytokinin tested (Zhang et al. 2006, Alonso et al. 2006). Similar cytokinin specificity of explants for multiple bud induction was found in shoot apex culture of $P$. roxburghii Sarg (Kalia et al. 2007).

In Pinus peuce culture as in Pinus pinea cotyledon culture (Alonso et al. 2006) number of buds was highest

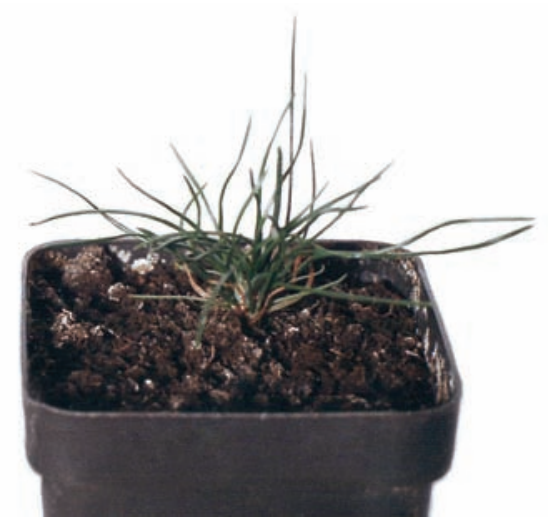

Fig. 1. Pinus peuce plantlet (14 months old) regenerated via adventive organogenesis. 
after longer exposure time, but longer exposure time influenced callus formation and affected bud elongation. In $P$. massoniana high BA concentrations (exceeding $4.4 \mu \mathrm{M})$ had a negative influence on shoot elongation, while the number of hyperhydric shoots increased (Zhang et al. 2006).

To promote bud elongation, medium without plant growth regulators (Stojičić et al. 1999, Sul and Korban 2004) or medium with lower level of cytokinin with auxin (Tang et al. 2004, Zhang et al. 2006) or auxin alone (Chalupa 1989) was usually applied. In Pinus radiata culture Sul and Korban (2004) have achieved successful shoot elongation by further decreasing the strength of medium used for bud induction, while Stange et al. (1999) have used medium with lowered sucrose content for shoot elongation. For Macedonian pine adventitious bud elongation, half-strength plant growth regulator-free GD medium supplemented with $2 \%$ sucrose and $0.5 \%$ $\mathrm{AC}$ was applied. Significance of AC in different aspects of tissue culture was recently reviewed by Thomas (2008). In Pinus heldreichii shoot apex culture, $0.5 \%$ AC

\section{References}

Alonso, P., Moncaleán, P., Fernández, B., Rodríguez, A., Centeno, M.L., Ordás., R.: An improved micropropagation protocol for stone pine (Pinus pinea L.). - Ann. Forest. Sci. 63: 879-885, 2006.

Chalupa, V.: Micropropagation of Larix decidua Mill. and Pinus sylvestris L. - Biol. Plant. 31: 400-407, 1989.

Gresshoff, P.M., Doy, C.H.: Development and differentiation of haploid Lycopersicon esculentum (tomato). - Planta 107: 161-170, 1972.

Janković, M.M.: [On the urgent need to plant a constant belt of the endemorelict Balkan pines Pinus heldreichii and Pinus peuce in the mountains of Serbia and Yugoslavia.] - Ecology 26: 61-67, 1991 [In Serbian].

Kalia, R.K., Arya, S., Kalia, S., Arya, I.D.: Plantlet regeneration from fascicular buds of seedling shoot apices of Pinus roxburghii Sarg. - Biol. Plant. 51: 653-659, 2007.

Kaul, K.: Factors influencing in vitro micropropagation of Pinus strobus L. - Biol. Plant. 32: 266-272, 1990.

Sommer, H.E., Brown, C.L., Kormanik, P.P.: Differentiation of plantlets in longlife pine (Pinus palustris Mill.) tissue cultured in vitro. - Bot. Gaz. 136: 196-200, 1975.

Stange, C., Prehn, D., Gebahuer, M., Arce-Johnson, P.: Optimization of in vitro culture conditions for Pinus radiata embryos and histological characterization of regenerated shoots. - Biol. Res. 32: 19-28, 1999.

Stojičić, D., Budimir, S.: Cytokinin-mediated axillary shoot was added to prevent exudation from the explant (Stojičić and Budimir 2004) and in zygotic embryo culture to promote shoot elongation during micropropagation (Stojičić et al. 1999).

The low efficiency of rooting remains a bottleneck for conifer propagation, thus reducing the possibilities of applying these techniques for large scale micropropagation. In Pinus peuce after pulse treatment with auxins up to 10 plants per explant were obtained within 36 weeks from culture initiation. IBA exerted stronger effect on isolated shoot survival and frequency of rooting than NAA. In Pinus massoniana IBA also had stronger effect than NAA in promoting root induction as well as for subsequent root growth (Zhang et al. 2006).

In conclusion, this study shows that multiplication of Pinus peuce seed material could be obtained through de novo organogenesis by adventitious buds formation. However, for increasing the effectiveness of existing propagation methods, improved protocols for rooting of adventitious shoots are needed.

formation in Pinus heldreichii. - Biol. Plant. 48: 477-479, 2004.

Stojičić, D., Budimir, S., Ćulafić, Lj.: Micropropagation of Pinus heldreichii. - Plant Cell Tissue Organ Cult. 59: 147150, 1999.

Sul, I.W., Korban, S.S.: Effects of salt formulation, carbon sources, cytokinins and auxin on shoot organogenesis from cotyledons of Pinus pinea L. - Plant Growth Regul. 43: 197205, 2004.

Tang, W., Harris, L.C., Outhavong, V., Newton, R.J.: The effect of different plant growth regulators on adventitious shoot formation from Virginia pine (Pinus virginiana Mill.) zygotic embryo explants. - Plant Cell Tissue Organ Cult. 78: 237-240, 2004.

Thomas, T.D.: The role of activated charcoal in plant tissue culture. - Biotechnol. Adv. 26: 618-631, 2008.

Vidaković, M.: Četinjače. Morfologija i Varijabilnost. [Conifers. Morphology and Variability.] - Yugoslav Academy of Science and Arts, Zagreb 1982. [In Serbocroat]

Vooková, B., Machava J., Šalgovičová, A., Kormuták, A.: Optimization of Algerian fir somatic embryos maturation. Biol. Plant. 54: 177-180, 2010.

Zhang, Y., Wei, Z., Xi, M., Shi, J.: Direct organogenesis and plant regeneration from mature zygotic embryos of masson pine (Pinus massoniana L.). - Plant Cell. Tissue Organ Cult. 84: 119-123, 2006. 